\title{
Evaluation of Borehole Geophysical Logs at the Sharon Steel Farrell Works Superfund Site, Mercer County, Pennsylvania
}

by Steven D. McAuley

In cooperation with the U.S. Environmental Protection Agency

Scientific Investigations Report 2004-5193 


\title{
U.S. Department of the Interior Gale A. Norton, Secretary
}

\author{
U.S. Geological Survey \\ Charles G. Groat, Director
}

U.S. Geological Survey, Reston, Virginia: 2004

Only available on the World Wide Web at http://pa.water.usgs.gov/pa_pubs.html

For more information about the USGS and its products:

Telephone: 1-888-ASK-USGS

World Wide Web: http://www.usgs.gov/

\footnotetext{
Any use of trade, product, or firm names in this publication is for descriptive purposes only and does not imply endorsement by the U.S. Government.

Although this report is in the public domain, permission must be secured from the individual copyright owners to reproduce any copyrighted materials contained within this report.
} 


\section{Contents}

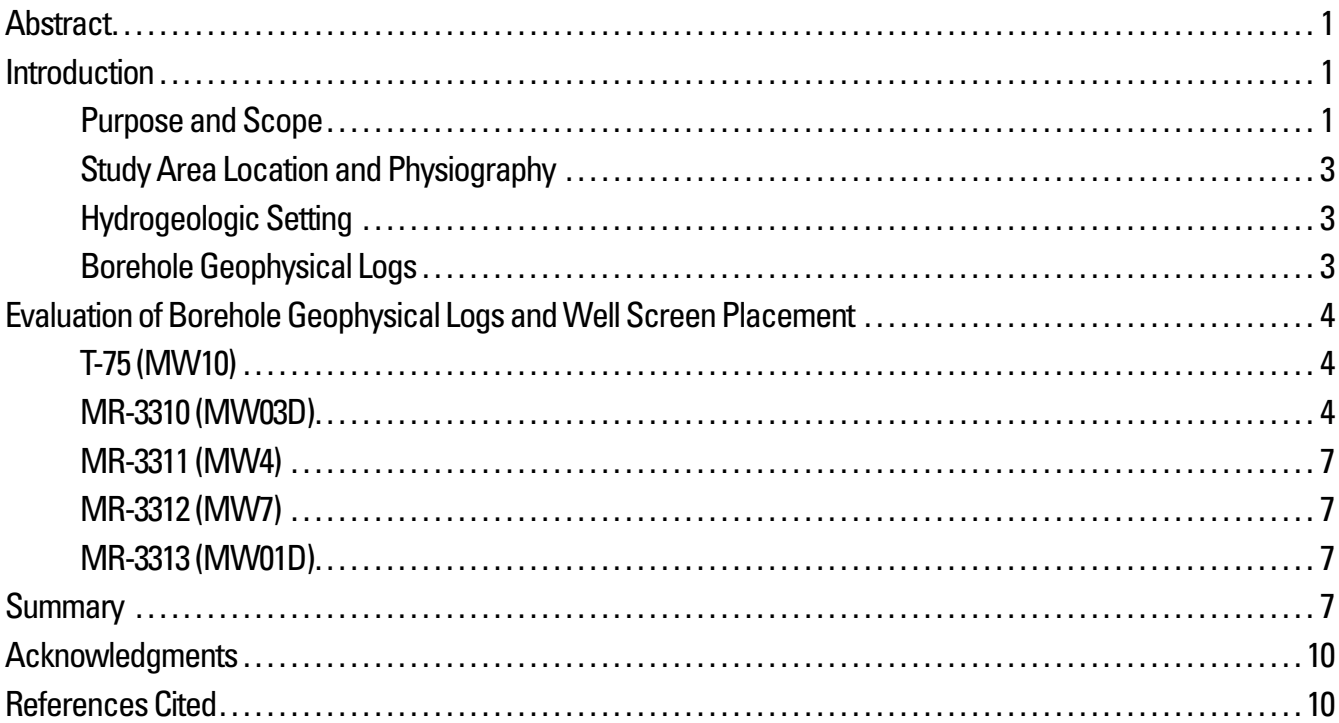

\section{Figures}

1. Map showing location of Sharon Steel Farrell Works Superfund Site and boreholes

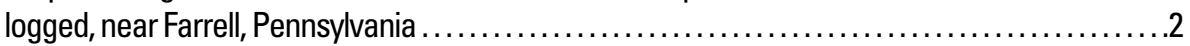

2. Borehole geophysical logs and water level in borehole T-75 (MW10), collected on April 14, 2003, at Sharon Steel Farrell Works Superfund Site, near Farrell, Pennsylvania. ......5

3-4. Borehole geophysical logs, water level, and direction of borehole flow under nonpumping conditions in:

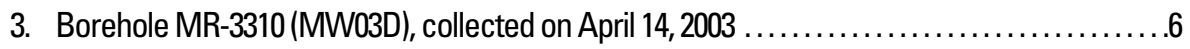

4. Borehole MR-3311 (MW4), collected on April 15, 2003 ............................

5. Borehole geophysical logs, water level, and direction of borehole flow under nonpumping and pumping conditions in borehole MR-3312 (MW7), collected

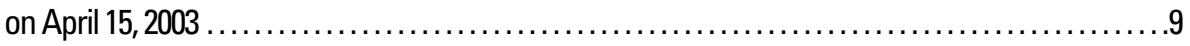

6. Borehole geophysical logs and water level in borehole MR-3313 (MW01D), collected

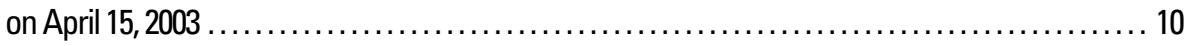

\section{Table}

1. Well-identification numbers, latitude and longitude location, depth logged, casing depth, and geophysical logs collected.... 


\section{Conversion Factors and Datum}

\begin{tabular}{|c|c|c|}
\hline Multiply & By & To obtain \\
\hline \multicolumn{3}{|c|}{ Length } \\
\hline inch (in.) & 2.54 & centimeter $(\mathrm{cm})$ \\
\hline foot (ft) & 0.3048 & meter $(\mathrm{m})$ \\
\hline \multicolumn{3}{|c|}{ Area } \\
\hline acre & 4,047 & square meter $\left(\mathrm{m}^{2}\right)$ \\
\hline \multicolumn{3}{|c|}{ Volume } \\
\hline gallon (gal) & 3.785 & liter (L) \\
\hline \multicolumn{3}{|c|}{ Flow rate } \\
\hline gallon per minute ( $\mathrm{gal} / \mathrm{min})$ & 0.06309 & liter per second $(\mathrm{L} / \mathrm{s})$ \\
\hline
\end{tabular}

Temperature in degrees Celsius $\left({ }^{\circ} \mathrm{C}\right)$ may be converted to degrees Fahrenheit $\left({ }^{\circ} \mathrm{F}\right)$ as follows:

${ }^{\circ} \mathrm{F}=\left(1.8 \times{ }^{\circ} \mathrm{C}\right)+32$

Temperature in degrees Fahrenheit $\left({ }^{\circ} \mathrm{F}\right)$ may be converted to degrees Celsius $\left({ }^{\circ} \mathrm{C}\right)$ as follows:

$$
{ }^{\circ} \mathrm{C}=5 / 9\left({ }^{\circ} \mathrm{F}-32\right)
$$

Vertical coordinate information is referenced to the North American Vertical Datum of 1988 (NAVD 88).

Horizontal coordinate information is referenced to the North American Datum of 1983 (NAD 83). 


\title{
Evaluation of Borehole Geophysical Logs at the Sharon Steel Farrell Works Superfund Site, Mercer County, Pennsylvania
}

\author{
by Steven D. McAuley
}

\section{Abstract}

On April 14-15, 2003, geophysical logging was conducted in five open-borehole wells in and adjacent to the Sharon Steel Farrell Works Superfund Site, Mercer County, Pa. Geophysical-logging tools used included caliper, natural gamma, singlepoint resistance, fluid temperature, and heatpulse flowmeter. The logs were used to determine casing depth, locate subsurface fractures, identify water-bearing fractures, and identify and measure direction and rate of vertical flow within the borehole. The results of the geophysical logging were used to determine the placement of borehole screens, which allows monitoring of water levels and sampling of water-bearing zones so that the U.S. Environmental Protection Agency can conduct an investigation of contaminant movement in the fractured bedrock.

Water-bearing zones were identified in three of five boreholes at depths ranging from 46 to 119 feet below land surface. Borehole MR-3310 (MW03D) showed upward vertical flow from 71 to 74 feet below land surface to a receiving zone at $63-68$ feet below land surface, permitting potential movement of ground water, and possibly contaminants, from deep to shallow zones. No vertical flow was measured in the other four boreholes.

\section{Introduction}

The Sharon Steel Farrell Works Superfund Site is in Mercer County, southwest of Farrell, Pa., at and near the border between Ohio and Pennsylvania (fig. 1). The site was a disposal area for slag and spent pickle liquor acid (an acidic bath solution, in this case containing hydrochloric, sulfuric, and chromic acid, used in industrial cleaning or processing) from the former Sharon Steel Corporation Farrell Works, located across the Shenango River.

Beginning about 1900, the Sharon Steel Corporation used the area across the Shenango River, west and southwest of the manufacturing plant, to dispose of blast furnace slag, electric arc furnace slag, basic oxygen furnace slag, and sludge. From 1949 to 1981 , millions of gallons of spent pickle liquor acid were dumped over the slag (CDM Federal Programs Corpora- tion, 2001). It was thought that the acid would partially evaporate and then be neutralized by the slag. Ground-water contamination resulted from this activity. Contaminants detected in ground water included arsenic, lead, and chromium (CDM Federal Programs Corporation, 2001).

A Remedial Investigation/Feasibility Study (RI/FS), phase 2, is being conducted at the Sharon Steel Farrell Works Superfund Site by TetraTech/Black \& Veach (TT/B\&V). The investigation was focused on the shallow unconsolidated sediments, but the U.S. Environmental Protection Agency (USEPA) identified a need to monitor the bedrock aquifer. As part of the RI/FS, TT/B\&V installed five boreholes to monitor the hydraulic head (water level) and chemical quality of the bedrock aquifer beneath the site (Black \& Veach Special Projects Corporation, 2002). Borehole geophysical logging of the five bedrock monitor wells was needed to identify water-bearing fractures and to determine optimal screen intervals for use by the USEPA in determining contaminant movement in the fractured bedrock.

\section{Purpose and Scope}

This report describes borehole geophysical logs collected by the U.S. Geological Survey (USGS) in five boreholes at the Sharon Steel Farrell Works Superfund Site during April 14-15, 2003 (table 1). The results of borehole geophysical logging and flowmeter surveys performed by the USGS were used to (1) determine casing depth, (2) locate subsurface fractures, (3) identify water-bearing fractures, (4) identify zones of potential vertical flow within the borehole, (5) measure direction and rate of vertical borehole flow to monitor and evaluate contaminant movement, and (5) select the most appropriate depths to screen boreholes. This information will be used by the USEPA in conducting an investigation of contaminant movement in the fractured bedrock. 


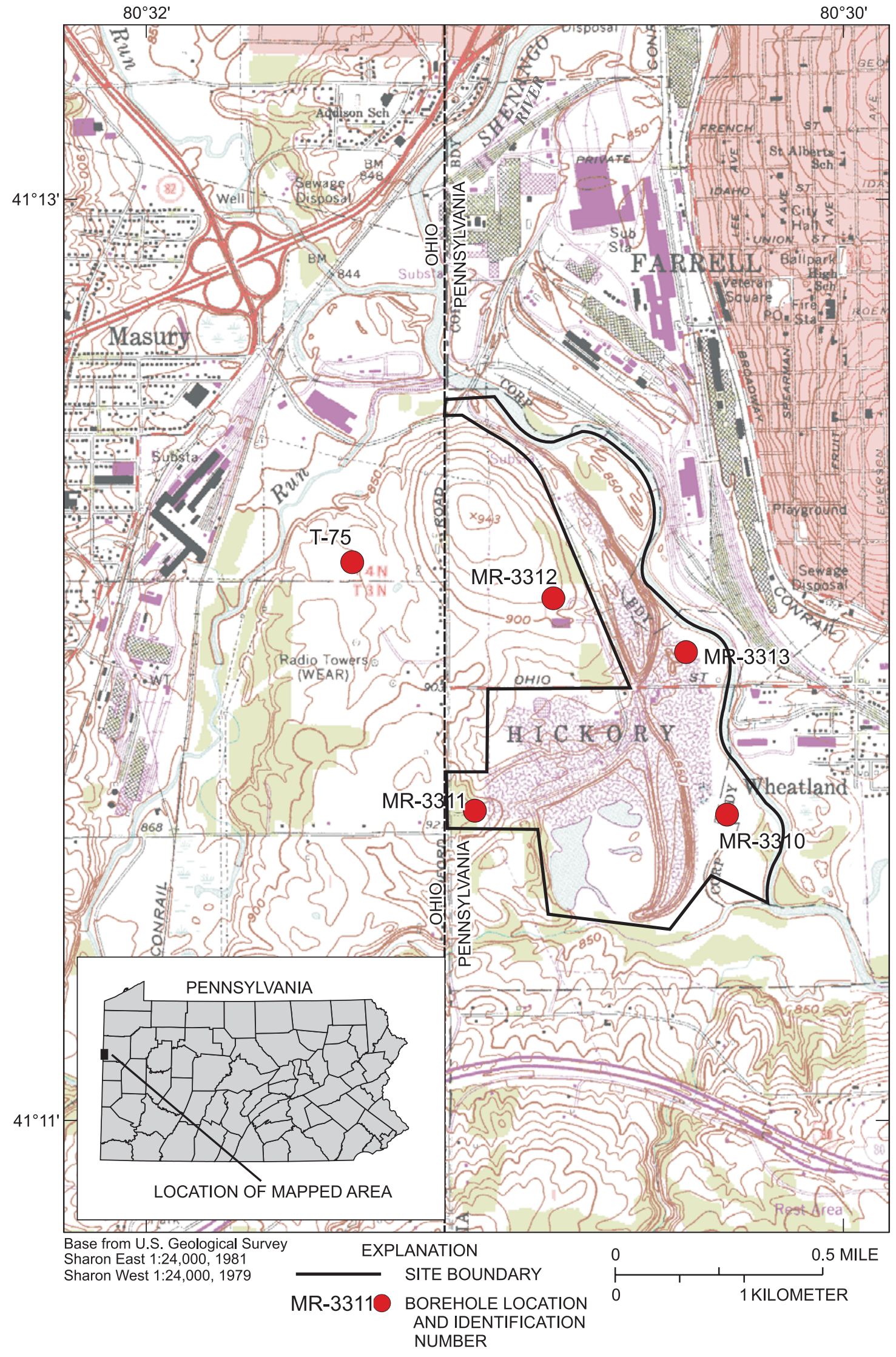

Figure 1. Location of Sharon Steel Farrell Works Superfund Site and boreholes logged, near Farrell, Pennsylvania. 
Table 1. Well-identification numbers, latitude and longitude location, depth logged, casing depth, and geophysical logs collected.

[Logs collected: C, caliper; G, natural gamma; R, single-point resistance; $\mathrm{T}$, temperature; $\mathrm{V}$, heatpulse flowmeter]

\begin{tabular}{ccccc}
\hline $\begin{array}{c}\text { U.S. } \\
\text { Geological } \\
\text { Survey } \\
\text { well- } \\
\text { identifica- } \\
\text { tion } \\
\text { number } \\
\text { (fig. 1) }\end{array}$ & $\begin{array}{c}\text { Site } \\
\text { number }\end{array}$ & $\begin{array}{c}\text { Latitude/ } \\
\text { longitude } \\
\text { (degrees, } \\
\text { minutes, } \\
\text { seconds) }\end{array}$ & $\begin{array}{c}\text { Well } \\
\text { depth } \\
\text { logged } \\
\text { (feet } \\
\text { below } \\
\text { land } \\
\text { Casing } \\
\text { depth } \\
\text { (feet } \\
\text { below } \\
\text { land }\end{array}$ & $\begin{array}{c}\text { Logs } \\
\text { collected }\end{array}$ \\
\hline surface)
\end{tabular}

\section{Study Area Location and Physiography}

The Sharon Steel Farrell Works Superfund Site is within the glaciated section of the Appalachian Plateaus Physiographic Province in Mercer County, in western Pennsylvania, on 400 acres of land within $100 \mathrm{ft}$ of the Ohio border. The site is on the Sharon West 7.5-minute USGS quadrangle (fig. 1). The site occupies a transition zone between a commercial and industrial area to the north and west and the rural and residential areas to the west and south of the site. The eastern border of the site is formed by the Shenango River, which flows generally in a southeasterly direction. Approximately 100 acres of wetlands are within the site boundaries. The site is within the 100- and 500-year floodplains of the Shenango River, and areas of the site west and south of the river are higher in elevation than areas north and east of the river by $100 \mathrm{ft}$ or more.

\section{Hydrogeologic Setting}

The site is underlain by unconsolidated deposits of sand, silt, and clay to depths of 65 to $120 \mathrm{ft}$. Four hydrostratigraphic units have been identified at the site (CDM Federal Programs Corporation, 2001). A shallow, unconsolidated aquifer composed of silt and sand occurs at 10 to $30 \mathrm{ft}$ below land surface (bls). A silt and clay semi-confining unit underlies the shallow aquifer to $20 \mathrm{ft}$ bls. A deep aquifer of sand and gravel, from 70 to $120 \mathrm{ft}$ bls, underlies the semi-confining unit, and bedrock underlies the deep aquifer below $120 \mathrm{ft}$ bls. The bedrock consists of Mississippian age shales and sandstones of the Cuyahoga Group.
Ground water occurs and moves in the pore spaces of the unconsolidated sediments and fractures in the bedrock.

Regional ground-water flow is generally from upland areas to valleys; thus, the site situated along the valley of the Shenango River is in an area of regional ground-water discharge. Locally, ground-water flow in the shallow, unconsolidated aquifer is to the east and southeast (CDM Federal Programs Corporation, 2001).

\section{Borehole Geophysical Logs} USGS:

The following geophysical logs were collected by the

1. caliper,

2. natural gamma,

3. single-point resistance (electrical),

4. fluid temperature,

5. fluid velocity (heatpulse flowmetering) if borehole flow was indicated by the fluid-temperature logs.

Borehole geophysical logs provide information on location and orientation of fractures, water-producing and waterreceiving zones, intervals of vertical borehole flow, quantification of borehole flow, lithologic correlation, and borehole construction.

Caliper logs record the average borehole diameter, which may be related to fractures, lithology, or drilling methods. Caliper logs can be used to identify fractures and possible waterproducing or water-receiving zones and correct other geophysical logs for changes in borehole diameter. Caliper logs also can be correlated with fluid-temperature logs and heatpulse flowmetering to further identify fractures and water-producing and water-receiving zones.

The natural-gamma or gamma log measures the naturalgamma radiation (photons) activity, in counts per second, emitted from all rocks. The most common emitters of gamma radiation are uranium-238, thorium-232, their daughter elements, and potassium-40. These radioactive elements are concentrated in clays by adsorption, precipitation, and ion exchange. Finegrained sediments, such as shale or siltstone, usually emit more gamma radiation than sandstone, limestone, or dolomite. The gamma $\log$ can be collected in the fluid-filled, dry-cased, or uncased parts of a borehole. However, casing does reduce the gamma response. The gamma log is used to correlate geologic units between boreholes (Keys, 1990).

The single-point-resistance log records the electrical resistance of a formation between the probe in a water-filled borehole below casing and an electrical ground at land surface. Generally, electrical resistance increases with formation grain size and decreases with borehole diameter, water-producing fractures, and increasing concentration of dissolved solids of borehole water. The single-point-resistance log is used to correlate stratigraphy between boreholes and may help identify waterproducing zones (Keys, 1990). 


\section{Evaluation of Borehole Geophysical Logs at the Sharon Steel Farrell Works Superfund Site, Mercer County, Pennsylvania}

A fluid-temperature log provides a continuous record of the vertical variation of temperature in the water in a borehole. Temperature logs are used to identify water-producing and water-receiving zones and to determine zones of vertical borehole flow. Intervals of vertical borehole flow are characterized by little or no temperature gradient (Williams and Conger, 1990).

The direction and rate of borehole-water movement was determined by the use of a heatpulse flowmeter. The heatpulse flowmeter operates by heating a small volume of water between two sensitive thermistors (heat sensors) located the same distance from the heat source. A measurement of direction and rate is computed when a peak temperature is recorded by one of the thermistors. A flexible diverter is used to block the annular space around the tool to channel all flow through the measurement channel. The range of flow measurement is about $0.01-$ $1.5 \mathrm{gal} / \mathrm{min}$ in a 2- to 10-in.-diameter borehole (Conger, 1996; Keys, 1990).

Some heatpulse-flowmeter measurements may be influenced by (1) poor seal integrity between the borehole and heatpulse flowmeter and (2) contributions of water from storage within the borehole. If the seal between the borehole and flowmeter is not complete, some water can bypass the flowmeter, resulting in measurements of flow that are less than the actual rate. Although the heatpulse flowmeter is a calibrated probe, the data are used primarily as a relative indicator to identify waterproducing or water-receiving zones.

In this study, the heatpulse flowmeter was used to identify borehole flow under static (nonpumping) conditions at depths at which the fluid-temperature logs indicated the possibility of flow. An attempt also was made to repeat the flowmeter survey while pumping the borehole at a rate of less than $1 \mathrm{gal} / \mathrm{min}$. The bedrock boreholes may have low yields (less than $1 \mathrm{gal} / \mathrm{min}$ ); thus, drawdown may not stabilize and flowmetering under pumping conditions may not be possible.

\section{Evaluation of Borehole Geophysical Logs and Well Screen Placement}

Locations of boreholes logged are shown in figure 1 . The locational, borehole-identification, and other data for boreholes logged are presented in table 1.

\section{T-75(MW10)}

The caliper log shows the total depth of the borehole is $76 \mathrm{ft}$ (fig. 2). The caliper log indicates the borehole is cased with 4-in.-diameter casing to $46 \mathrm{ft}$ bls. The water level in the borehole at the time of logging was $5.70 \mathrm{ft}$ bls. The measuring point (MP) was the top of casing, $1.4 \mathrm{ft}$ above land surface. The caliper log indicates a fracture from about 46.5 to $48.5 \mathrm{ft}$ bls. The geologic log indicates silty clay with some coarse sand interbedded from surface to $27 \mathrm{ft}$ bls, weathered shale from 27 to
$44 \mathrm{ft}$ bls, and competent shale from 44 to $76 \mathrm{ft}$ bls (Michael Napolitan, Black \& Veach Special Projects Corporation, written commun., 2004). The gamma log shows a general increase in activity below $45 \mathrm{ft}$ bls because the probe is reading in the open uncased part of the borehole. Variations in gamma activity from $45 \mathrm{ft}$ bls to the bottom of the borehole probably indicate slight differences in sand content within the shale as described in the geologic log (Michael Napolitan, Black \& Veach Special Projects Corporation, written commun., 2004). The single-

point-resistance log shows decreased electrical resistance at 57 and $68 \mathrm{ft}$ bls. The single-point-resistance log is a mirror image of the gamma log in most places except for the interval from about 46 to $47 \mathrm{ft}$ bls. This area may be too close to the casing bottom to get a correct reading from the single-point-resistance logging tool. The fluid-temperature log is likely showing the effect of cooling with depth from near-surface warming; the log then shows the effect of the geothermal gradient as temperature gradually increases. The heatpulse flowmeter was not run. A borehole screen placed from 44 to $54 \mathrm{ft}$ bls would include the fracture from 46.5 to $48.5 \mathrm{ft}$ bls.

\section{MR-3310 (MW03D)}

The caliper log shows the total depth of the borehole is $113.7 \mathrm{ft}$ bls (fig. 3). The bottom of the borehole was covered with a layer of thick mud. The borehole is cased with 4-in.diameter casing to $63 \mathrm{ft}$ bls. The water level in the borehole at the time of logging was $1.3 \mathrm{ft}$ bls. The MP was the top of casing, $2.5 \mathrm{ft}$ above land surface. The caliper log shows a series of fractures from 63 to 68,71 to 74 , and 79 to $82 \mathrm{ft}$ bls. The geologic $\log$ of the borehole drilling shows silt and clay to $51 \mathrm{ft} \mathrm{bls,}$ mostly silty sand to $61 \mathrm{ft}$ bls, sandstone to $81 \mathrm{ft}$ bls, siltstone to $89 \mathrm{ft}$ bls, sandstone to $98 \mathrm{ft}$ bls, and siltstone to $113 \mathrm{ft}$ bls (Michael Napolitan, Black \& Veach Special Projects Corporation, written commun., 2004). The gamma log shows increases in activity interspersed with decreases in activity from 60 to $113 \mathrm{ft}$ bls. This change in activity indicates silty zones in the sandstone and sandy zones in the siltstone. Over the interval from 60 to $98 \mathrm{ft}$ bls, gamma activity generally increases. The single-point-resistance log is a mirror image of the gamma log. The fluid-temperature log generally shows an increase with depth. Sudden or sharp changes in temperature, however, occur at the fracture zones. Minor temperature increases are shown at 71-74 and 79-82 ft bls, coinciding with fracture zones indicated by the caliper $\log$, and also at $112 \mathrm{ft}$ bls. Under nonpumping conditions, the heatpulse flowmeter measured upward flow at $0.24 \mathrm{gal} / \mathrm{min}$ from the fracture at about $71-74 \mathrm{ft}$ bls. Water exits the borehole at the fracture at 63-68 ft bls. No flow was measurable at 77, 86, 94, and $104 \mathrm{ft}$ bls (fig. 3), although there was a minor turbulence at $94 \mathrm{ft}$ bls. A borehole screen placed from 69 to $75 \mathrm{ft}$ bls would include the water-producing fracture at 71$74 \mathrm{ft}$ bls. If the water entering the borehole at the fracture opening from 71 to $74 \mathrm{ft}$ bls is contaminated, cross-contamination of the receiving zone could occur. 


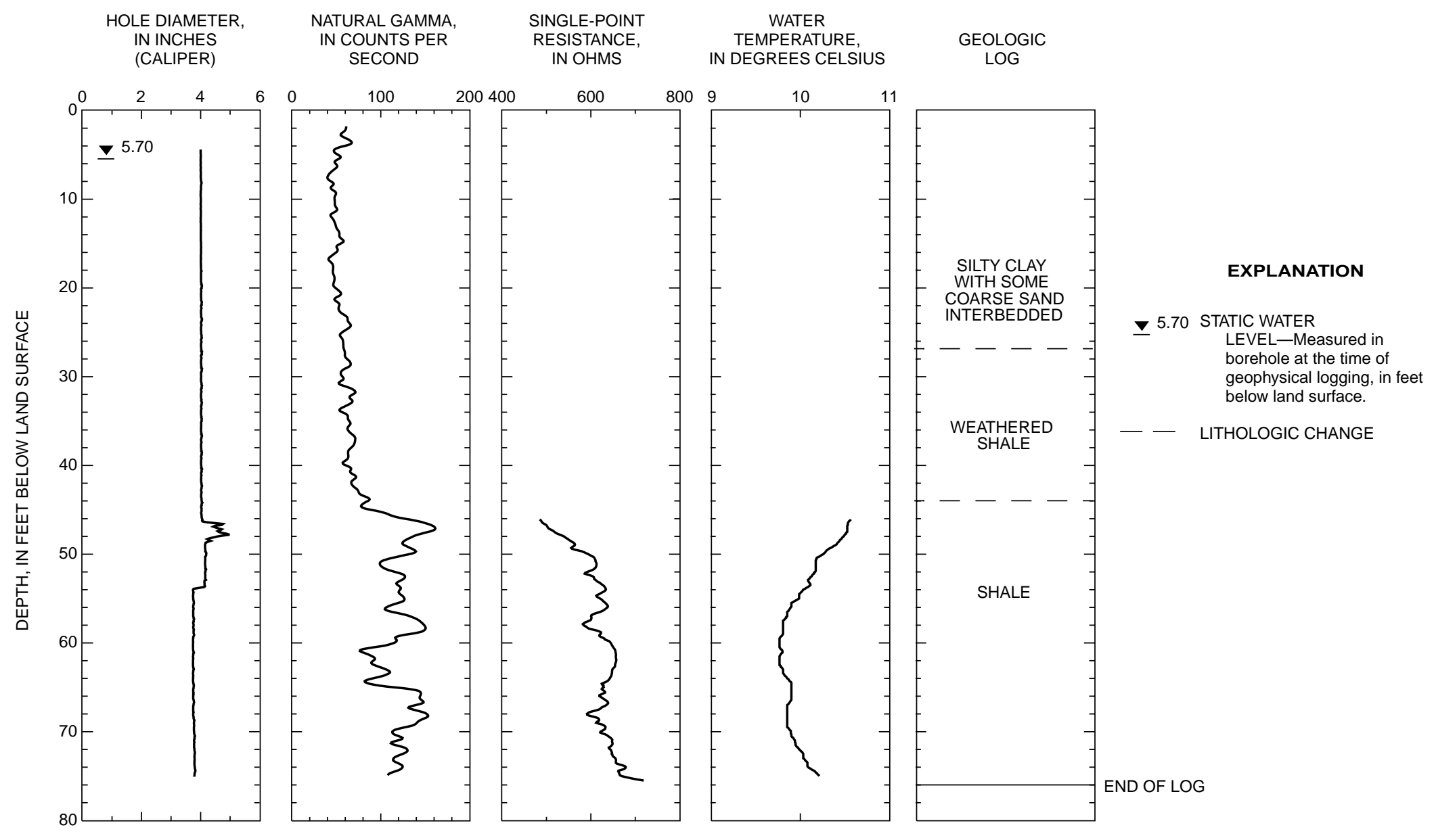

Figure 2. Borehole geophysical logs and water level in borehole T-75 (MW10), collected on April 14, 2003, at Sharon Steel Farrell Works Superfund Site, near Farrell, Pennsylvania (Geologic log from Black \& Veach Special Projects Corporation, written commun. 2004). 


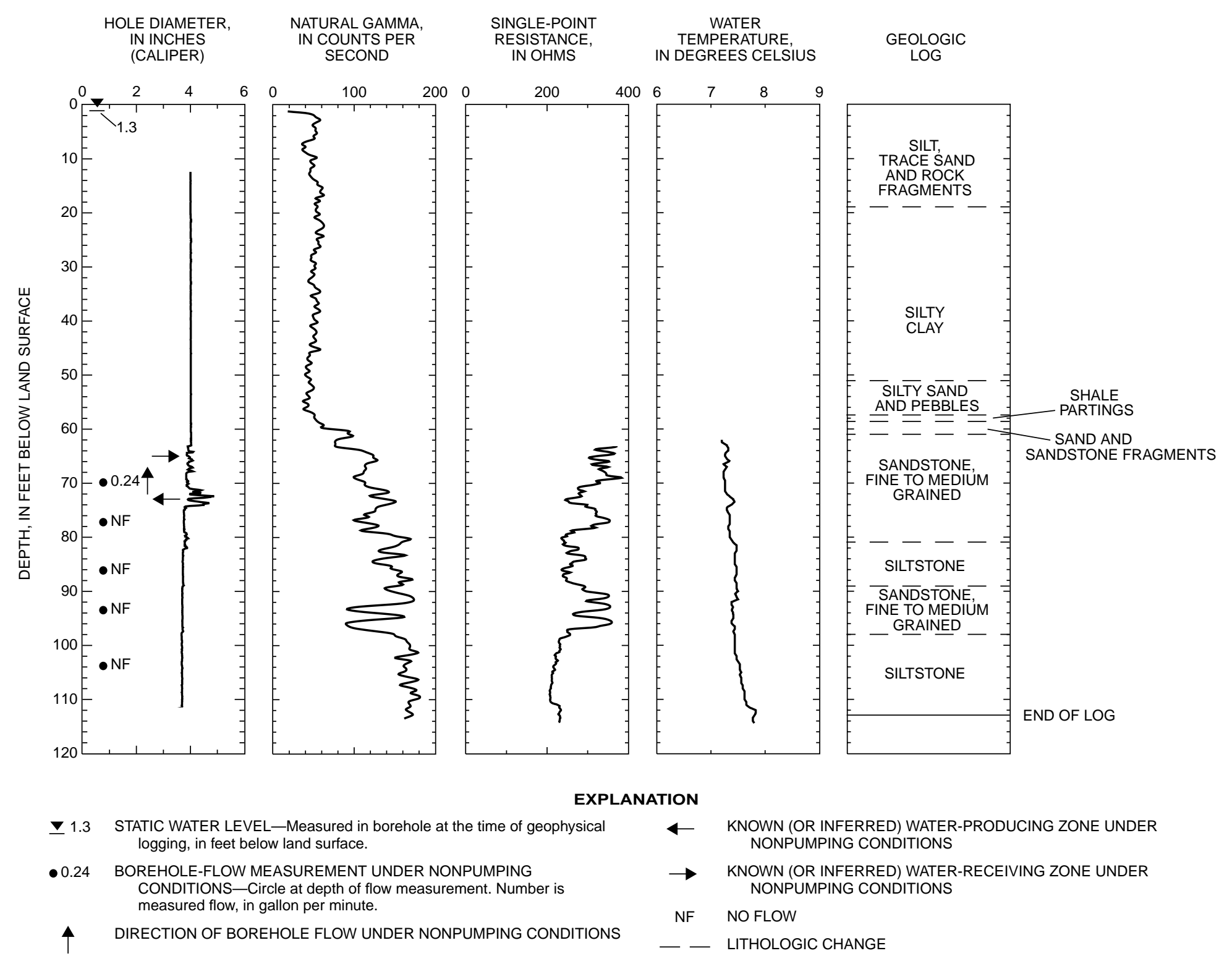

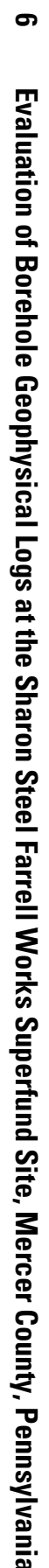

Figure 3. Borehole geophysical logs, water level, and direction of borehole flow under nonpumping conditions in borehole MR-3310 (MW03D), collected on April 14, 2003, at Sharon Steel Farrell Works Superfund Site, near Farrell, Pennsylvania (Geologic log from Black \& Veach Special Projects Corporation, written commun. 2004). 


\section{MR-3311 (MW4)}

The caliper log shows the total depth of the borehole is $146 \mathrm{ft}$ bls (fig. 4). The bottom of the borehole was covered with a layer of thick mud. The gamma, single-point-resistance, and fluid-temperature logs gave readings through the mud to about $150 \mathrm{ft}$ bls. The borehole is cased with 4-in.-diameter casing to $108 \mathrm{ft}$ bls. The water level in the borehole at the time of logging was $49.23 \mathrm{ft}$ bls. The MP was the top of casing, $3.0 \mathrm{ft}$ above land surface. The geologic log indicates sand, sandy silt, and silty sand to $100 \mathrm{ft}$ bls, gravel with siltstone and sandstone fragments to $115 \mathrm{ft}$ bls, and siltstone throughout the rest of the borehole (Michael Napolitan, Black \& Veach Special Projects Corporation, written commun., 2004). The caliper log shows a fracture zone from 108 to $110 \mathrm{ft}$ bls and minor fractures from 112 to $116 \mathrm{ft}$ bls. The gamma log shows increases in activity interspersed with decreases in activity from $111 \mathrm{ft}$ bls to the borehole bottom. This change in activity indicates sandy zones within the siltstone, probably as interbedded sandstone. The single-point-resistance log mirrors the gamma log and indicates stratigraphic changes. The fluid-temperature log shows an increase in temperature with depth, indicating no vertical borehole flow. A slight change in the slope on the fluid-temperature $\log$ at $110 \mathrm{ft}$ bls coincides with the major fracture zone indicated on the caliper log, which may indicate minor lateral borehole flow. The fluid-temperature log shows increasing temperature with depth that is indicative of the geothermal gradient. Under nonpumping conditions, the heatpulse flowmeter measured no flow at $130 \mathrm{ft}$ bls. A screen set from 108 to $118 \mathrm{ft}$ bls would include the major fractures from 108 to $116 \mathrm{ft}$ bls.

\section{MR-3312 (MW7)}

The caliper log shows the total depth of the borehole is $77 \mathrm{ft}$ bls (fig. 5). The borehole is cased with 5-in.-diameter casing to $20 \mathrm{ft}$ bls. The water level in the borehole at the time of logging was $7.36 \mathrm{ft}$ bls. The MP was the top of casing, $0.5 \mathrm{ft}$ bls. The caliper log showed no apparent fracture zones. The geologic log indicates silty clay with traces of sand and gravel to $20 \mathrm{ft}$ bls and shale from casing bottom to borehole bottom. The gamma log shows increases in activity interspersed with decreases in activity from 20 to $77 \mathrm{ft}$ bls that indicate sandy zones interspersed within the shale. The single-pointresistance log exhibits an inverse relation with the gamma log. The changes in fluid temperature are gradual after initial changes from 20 to $23 \mathrm{ft}$ bls, indicating the absence of waterproducing or water-receiving zones. Under nonpumping conditions, the heatpulse flowmeter measured no flow at 34 and $56 \mathrm{ft}$ bls. A low-volume pump was placed into the borehole at a depth of about $19 \mathrm{ft}$ bls. The heatpulse flowmeter was set at $34 \mathrm{ft}$ bls. No flow was measured at any depth in the borehole. The water level did not stabilize even at pumping rates that averaged about $0.4 \mathrm{gal} / \mathrm{min}$. Because the casing was below land surface and the borehole had no cap, rainwater may have filled up the borehole. Under present conditions, the borehole provides little useful information, does not clearly demonstrate a connection to a water-bearing zone, and could be abandoned and (or) plugged without loss of information about the flow system.

\section{MR-3313 (MW01D)}

The caliper log shows the total depth of the borehole is $119 \mathrm{ft}$ bls (fig. 6). The borehole is cased with 4-in.-diameter steel casing to $119 \mathrm{ft}$ bls. The water level in the borehole at the time of logging was $5.88 \mathrm{ft}$ bls. The MP was the top of casing, $2.4 \mathrm{ft}$ above land surface. A casing-depth indicator was run along the length of the casing and confirmed that the casing runs to $119 \mathrm{ft}$ bls, the entire length of the borehole. The geologic log shows gravel to $4 \mathrm{ft}$ bls, sandy silt and silt to $108 \mathrm{ft}$ bls, gravel to $115.5 \mathrm{ft}$ bls, and siltstone to $166 \mathrm{ft}$ bls. The geologic log reports water at $10 \mathrm{gal} / \mathrm{min}$ at $122 \mathrm{ft}$ bls. When drilling at $144 \mathrm{ft}$, the geologists log reports that the upper hole was collapsing. The entire hole below casing likely collapsed after the drilling tools were removed. Because the borehole was cased to the bottom, no fluid-temperature, single-point-resistance, or heatpulse-flowmeter logs were run. It is not necessary to set a screen in this borehole, and plugging of the hole would reduce the potential for migration of contaminants along the lower portion of the annular seal of the casing.

\section{Summary}

On April 14-15, 2003, the USGS, in cooperation with the USEPA, logged five boreholes drilled into the bedrock of the Mississippian-age Cuyahoga Group at the Sharon Steel Farrell Works Superfund Site, near Farrell, Pa. The borehole geophysical logging and flow measurements were conducted to (1) determine casing depth, (2) locate subsurface fractures, (3) identify water-bearing fractures, (4) identify zones of potential vertical flow within the borehole, (5) measure direction and rate of the vertical borehole flow to monitor and evaluate contaminant movement, and (6) select the most appropriate depths to screen boreholes. The USEPA will use this information to conduct an investigation of contaminant movement in the bedrock.

The boreholes logged ranged from 76 to $150 \mathrm{ft}$ in depth. Water-bearing zones were indicated in three of the five boreholes and ranged in depth from 46 to $119 \mathrm{ft}$ bls. Upward vertical flow from a water-bearing zone at $71-74 \mathrm{ft}$ bls to a water-bearing zone at $63-68 \mathrm{ft}$ bls was identified with the heatpulse flowmeter in borehole MR-3310 (MW03D) and could permit movement of ground water (and contaminants) from deeper bedrock to more shallow water-bearing zones. Optimal screen intervals ranged from 44 to $118 \mathrm{ft}$ bls. 

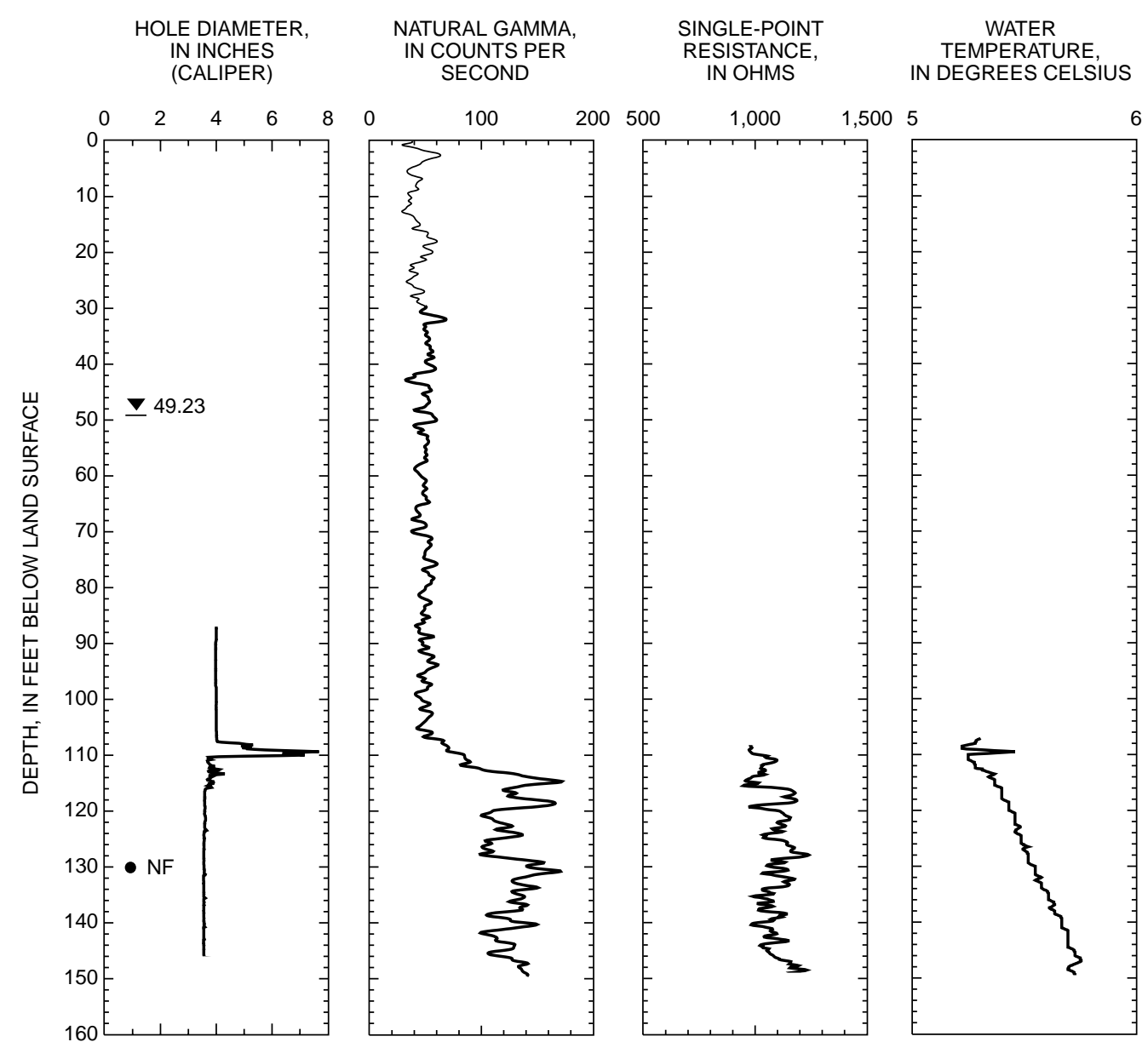

GEOLOGIC

$200500 \quad 1,000$ 1,5005
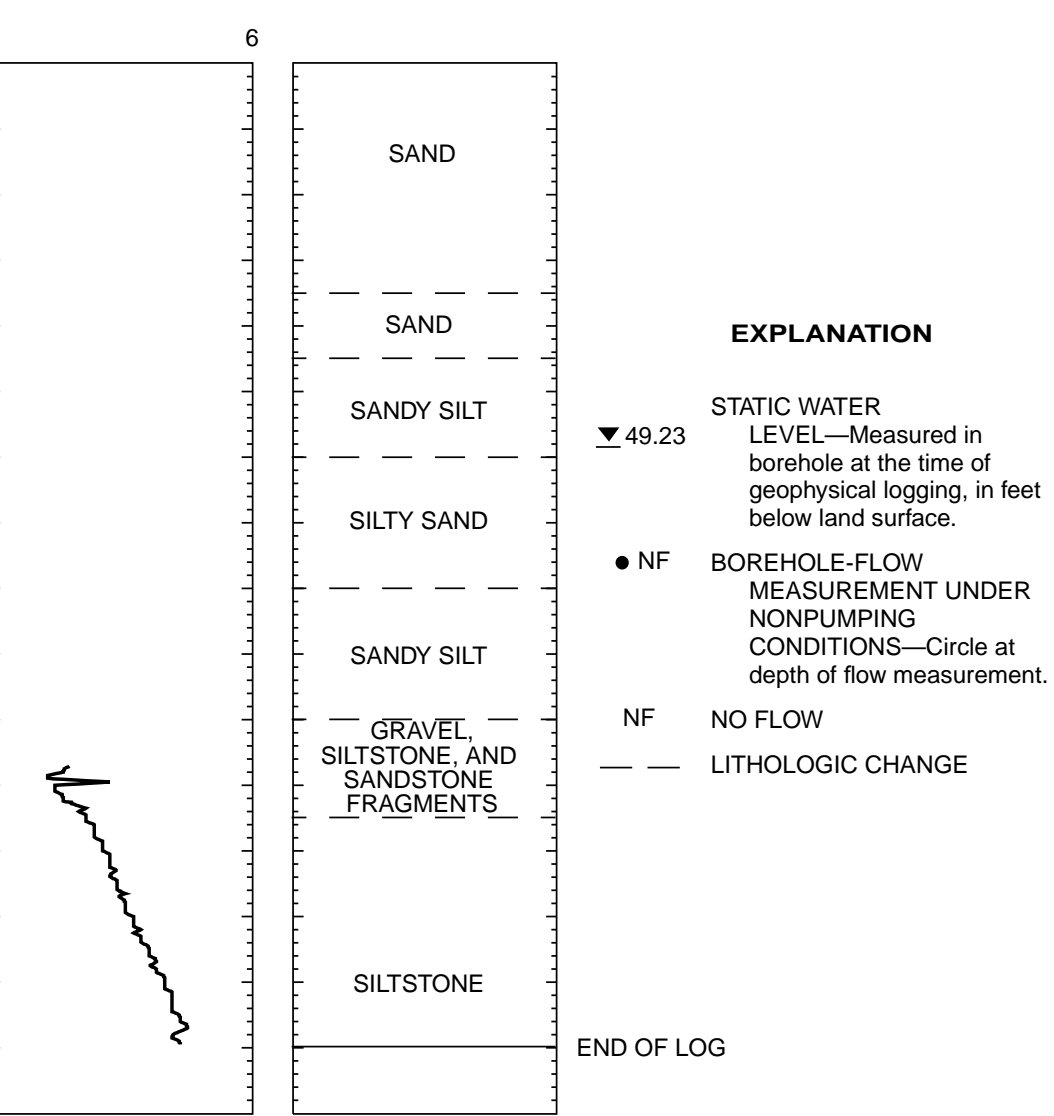

NF

NO FLOW

SILTSTONE, AND

Figure 4. Borehole geophysical logs, water level, and direction of borehole flow under nonpumping conditions in borehole MR-3311 (MW4), collected on April 15, 2003, at Sharon Steel Farrell Works Superfund Site, near Farrell, Pennsylvania (Geologic log from Black \& Veach Special Projects Corporation, written commun. 2004). 


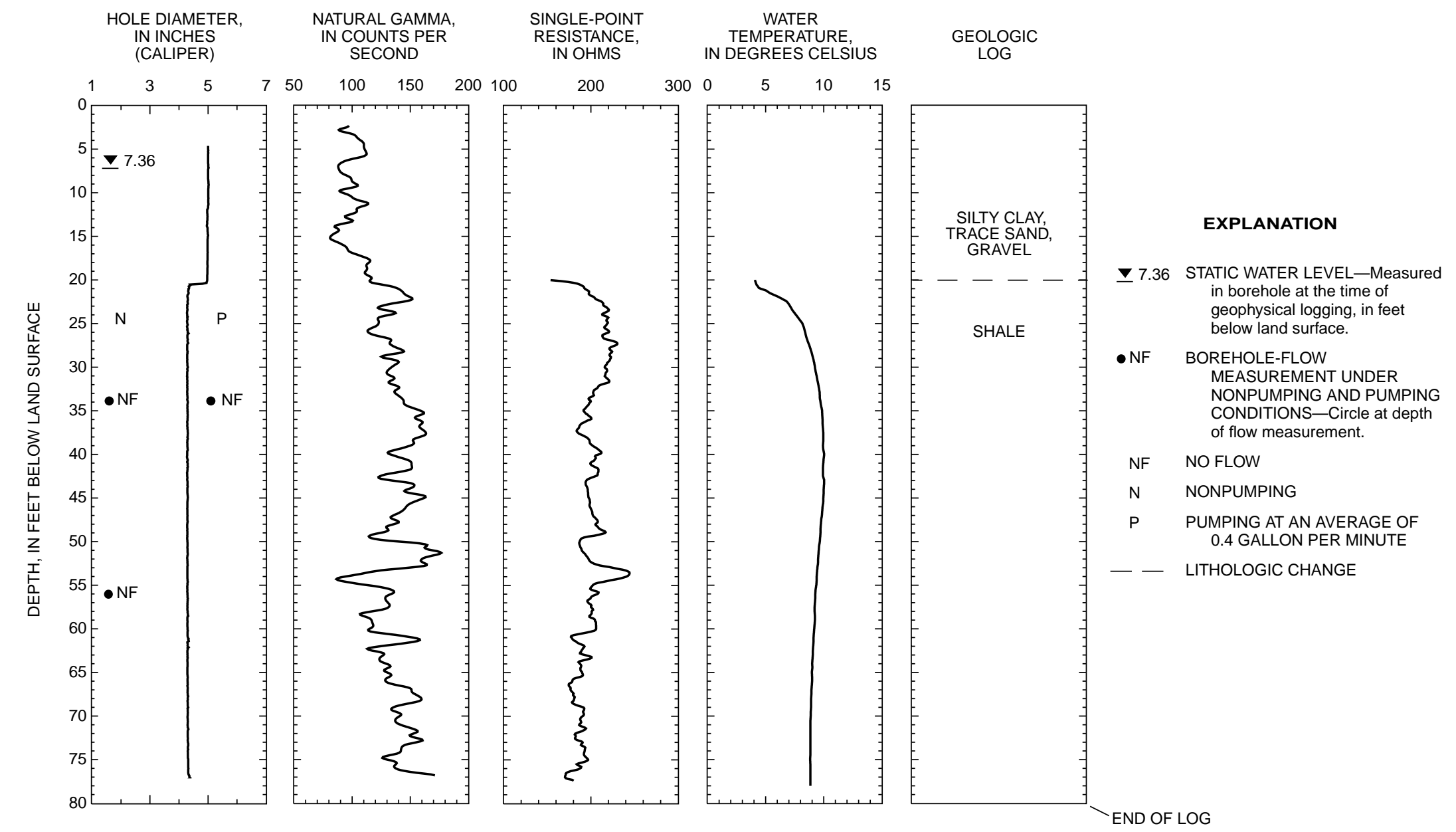

Figure 5. Borehole geophysical logs, water level, and direction of borehole flow under nonpumping and pumping conditions in borehole MR-3312 (MW7), collected on April 15, 2003, at Sharon Steel Farrell Works Superfund Site, near Farrell, Pennsylvania (Geologic log from Black \& Veach Special Projects Corporation, written commun. 2004). 

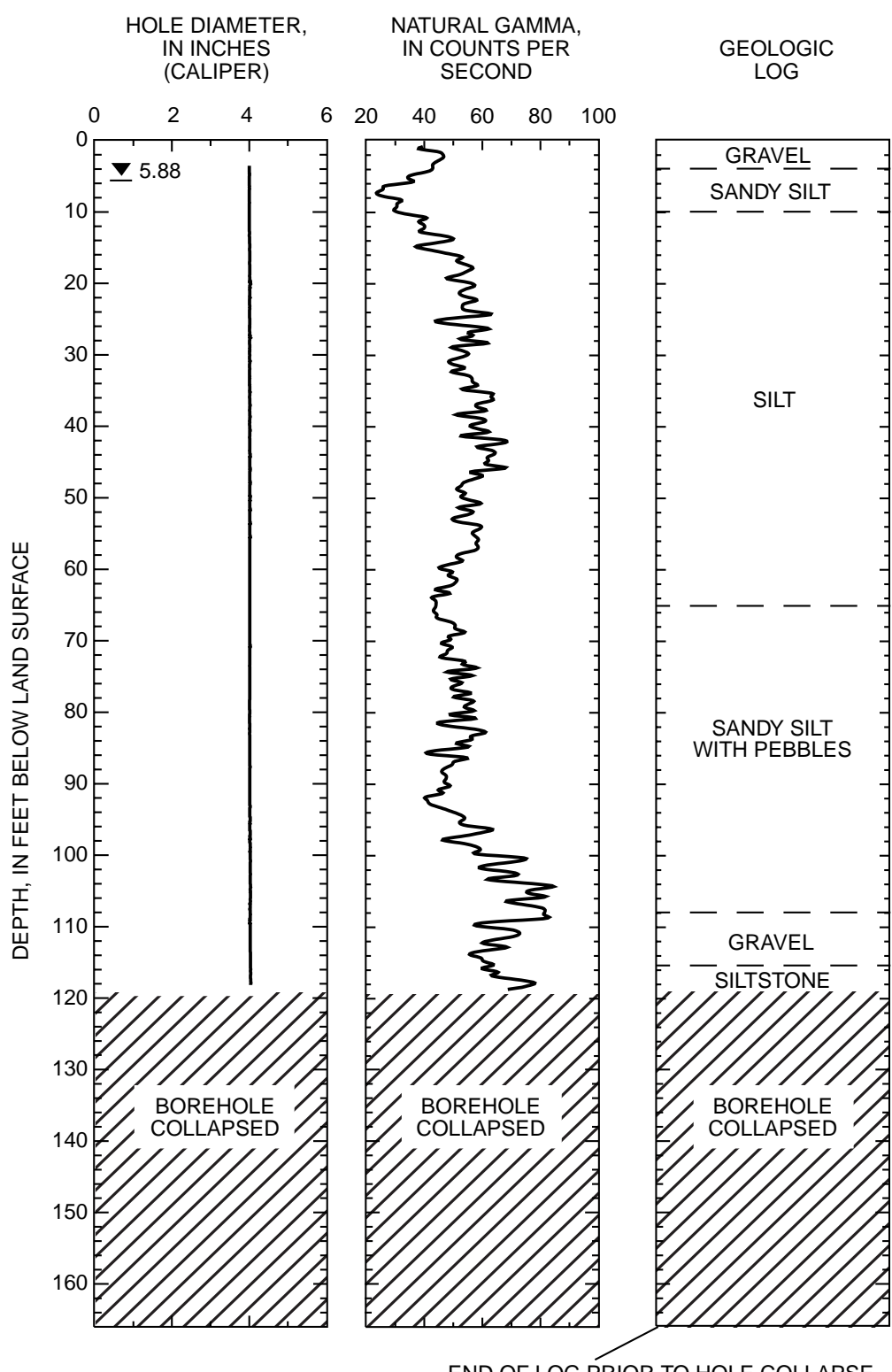

\author{
EXPLANATION \\ 叉 5.88 STATIC WATER LEVEL-Measured \\ in borehole at the time of geophys- \\ ical logging, in feet below land \\ surface. \\ - L LITHOLOGIC CHANGE
}

Figure 6. Borehole geophysical logs and water level in borehole MR-3313 (MW01D), collected on April 15, 2003, at Sharon Steel Farrell Works Superfund Site, near Farrell, Pennsylvania (Geologic log from Black \& Veach Special Projects Corporation, written commun., 2004).

\section{Acknowledgments}

The author thanks the U.S. Environmental Protection Agency (USEPA) Region III and TetraTech/Black \& Veach Special Projects Corporation for providing information about the study site. Randall Conger and Theodore Buckwalter, both of the USGS, are acknowledged for conducting the borehole geophysical surveys.

\section{References Cited}

Black \& Veach Special Projects Corporation, 2002, Draft sampling and analysis plan for Phase 2 Remedial Investigations, Sharon Steel-Farrell Works Superfund site, Mercer County, Pennsylvania, May 3, 2002: Response Action Contract No. 68-87-3-002.
CDM Federal Programs Corporation, 2001, Draft Phase 1 investigation report for Sharon Steel Farrell Works, Farrell, Pennsylvania, April 26, 2001: Document No. 013-RICO03DX.

Conger, R.W., 1996, Borehole geophysical logging for waterresources investigations in Pennsylvania: U.S. Geological Survey Fact Sheet 218-95, 4 p.

Keys, W.S., 1990, Borehole geophysics applied to groundwater investigations: U.S. Geological Survey Techniques of Water-Resources Investigations, book 2, chap. E2, 150 p.

Williams, J.H., and Conger, R.W., 1990, Preliminary delineation of contaminated water-bearing fractures intersected by open-hole bedrock wells: Ground Water Monitoring Review, Fall 1990, p. 118-121. 